\title{
DETERMINASI TRANSPARANSI APBDES PADA KABUPATEN KARAWANG
}

\author{
Sri Suartini \\ srisuartini_daw@yahoo.com; \\ Hari Sulistiyo \\ harisulistiyo68@gmail.com; \\ Syamsul Huda \\ syamsul.huda@fe.unsika.ac.id \\ Universitas Singaperbangsa Karawang
}

\begin{abstract}
Abstrak
Penelitian ini bertujuan untuk menguji pengaruh perencanaan, pelaksanaan , pengawasan terhadap transparansi APBDes di kabupaten Karawang. Penelitian ini menggunakan tiga variable bebas (independent) dan variable terikat (dependent), Variabel Perencanaan APBDes $\left(\mathrm{X}_{1}\right)$ Variabel Pelaksanaan APBDes $\left(\mathrm{X}_{2}\right)$, Variabel Pengawasan APBDes (X3), dan variabel Transparansi APBDes (Y). Populasi dalam penelitian ini adalah seluruh perangkat desa pada Kabupaten Karawang. Jumlah ideal pegawai setiap kelurahan adalah 17 orang dan kecamatan 30 orang. Jumlah responden dalam penelitian ini, adalah 100 responden. Penelitian ini menggunakan teknik kuesioner dalam mengumpulkan data.. untuk mendapatkan data penelitian.

Hasil penelitian secara parsial menunjukkan terdapat pengaruh Perencanaan APBDes $\left(\mathrm{X}_{1}\right)$ secara parsial terhadap Transparansi APBDes $(Y)$, Sig. $(0,00<\alpha(0,05)$ dan $t$ hitung $(10.120)>\mathrm{t}$ tabel $(0,6770)$ sehingga Ho ditolak. Pengaruh Pelaksanaan APBDes $\left(\mathrm{X}_{1}\right)$ secara parsial terhadap Transparansi APBDes (Y), nilai Sig. $(0,00<\alpha(0,05)$ dan t hitung $(12.328)>t$ tabel $(0,6770)$ sehingga Ho ditolak.Pengaruh Pengawasan APBDes(X3) terhadap TransparansiAPBDes (Y), nilai Sig. $(0,00<\alpha(0,05)$ dan $t$ hitung $(11.125)>t$ tabel $(1,675)$ sehingga Ho ditolak. Sedangkan secara simultan hasil perhitungan didapat nilai Sig. $(0,000)<$ $\alpha(0,05)$ dan $\mathrm{F}$ hitung $(79,143)>\mathrm{F}_{\text {tabel }}(3,09)$ sehingga Ho ditolak. Nilai $\mathrm{R}^{2}$ dari tabel Model Summary menunjukkan bahwa $71.4 \%$ dari variance Transparansi APBDes, dapat dijelaskan variabel Perencanaan APBDes, Pelaksanaan APBDes dan Pengawasan APBDes.

Kata Kunci: Perencanaan, Pelaksanaan, Pengawasan ,Transparansi APBDes
\end{abstract}

\section{Pendahuluan}

Pemberian terhadap Otonomi desa merupakan unit terdepan dalam pelayanan kepada masyarakat serta menjadikan landasan srategis yang akan mempengaruhi secara signifikan perwujudan keberhasilan semua program kerja . Dimana dalam penyelenggaraan pembangunan desa diperlukan adanya pengorganisasian yang mampu serta menggerakan masyarakat untuk berpartisipasi dalam pembangunan desa serta melaksanakan administrasi pembangunan desa yang semakin rasional ( Bambang suryono, 2; 2015 )

Dari peran pemerintah desa dalam memanfaatkan hasil potensi desa melalui APBDes sangat diharapkan karena APBDes merupakan instrumen yang sangat penting dalam rangka perwujudan tata pemerintahan yang baik di tingkat desa. Dengan kata lain tata pemerintahan yang baik diukur dari bagaimana pemerintah desa bekerja secara mandiridalam mengelola 
potensi-potensi yang ada di desa, sehingga pengelolaan APBDes yang disusun benar-benar berorientasi kepada peningkatan pembiayaan pembangunan dan kesejahteraanmasyarakat desa serta memenuhi prinsip-prinsip seperti transparansi, partisipasi dan akuntabilitas. ( Bawias,Masje \& Sony 2015 )

Pemerintah Desa dipimpin oleh Kepala Desa dan dibantu perangkat Desa sebagai unsur penyelenggara Pemerintahan Desa seperti Badan Permusyawaratan Desa atau yang disebut dengan BPD adalah lembaga yang melaksanakan fungsi pemerintahan yang anggotanya merupakan wakil dari penduduk Desa berdasarkan keterwakilan wilayah dan ditetapkan secara demokratis dan Sekertaris Desa. Sekretaris Desa (Sekdes) mempunyai peran penting di masyarakat. ( Sebagaimana bahwa dalam Undang-Undang No 32 tahun 2004 ) tentang Pemerintahan Daerah, Pemerintahan adalah kegiatan penyelenggaran Negara gunamemberikan pelayanan dan perlindungan bagi segenap warga masyarakat melakukan pengaturan, memobilisasi semua sumber daya yang diperlukan guna tercapainya pembangunan. Keberhasilan tidak begitu mudah tercapai akan tetapi faktor-faktor pendukung harus diutamakan seperti Sumber Daya Manusia dan Sumber Daya Alam.

Menurut ketentuan umum pasal 1 ayat 6, Permendagri Nomor 113 Tahun 2014, menyatakan bahwa pengelolaan keuangan desa adalah keseluruhan kegiatan yang meliputi perencanaan, pelaksanaan, penatausahaan, pelaporan, dan pertanggungjawaban keuangan desa. Batasan ini sungguh jelas dan point pertama yang patut kita pahami bersama adalah perencanaan. Dimana perencanaan telah menjadi icon sekaligus syarat dasar bagi pengelolaan keuangan desa. Oleh Karena itu, sebagai penyelenggara, pemerintah desa wajib menyediakan dokumen perencanaan sebelum mengelola keuangan desa.

Pengelolaan keuangan desa harus didasarkan pada peraturan desa tentang Anggaran Pendapatan dan Belanja Desa (APBDes) sebagai bentuk transparansi dan akuntabilitas rencana penerimaan dan pengeluaran desa. Selanjutnya berdasarkan APBDes, pemerintah desa melaksanakan pemungutan pendapatan dan pengeluaran belanja dalam rangka pembangunan desa. Sebagai bentuk pertanggungjawaban pelaksanaan APBDes, selanjutnya pemerintah desa harus menyusun laporan keuangan. Laporan keuangan desa adalah suatu bentuk kebutuhan transparansi dan akuntabilitas pelaksanaan APBDes dalam aktivitas pengelolaan sumber daya publik. Pencapaian suatu transparansi dan akuntabilitas pengelolaan keuangan pemeritahan desa harus dapat diwujudkan dengan menerapkan sebuah sistem pengelolaan keuangan pemerintahan desa yang transparan dan akuntabel. Dengan pengelolaan keuangan desa yang dilaksanakan dengan baik, diharapkan kinerja pemerintahan desa akan meningkat dan tercipta Good Government Governance. ( Suryo Pratolo, Winarso ,2, 2013)

\section{Tinjauan Teoritis dan Pengembangan Hipotesis}

Perencanaan adalah proses merumuskan suatu kegiatan dalam rangka memperoleh hasil yang diharapakan dalam kegiatan tersebut (The Liang Gie, 1995, hal 23). Sebelum APBDes dibahas maka harus didahului dengan tahapan musyawarah yaitu tahap pertama, musyawarah pembangunan di tingkat dusun untuk menyerap aspirasi dari masing-masing RT/RW, musyawarah ini dipimpin oleh masing- masing Kepala Dusun. Hasil-hasil dari penyerapan aspirasi ditingkat dusun dituangkan dalam bentuk usulan yang akan dibawa tingkat Musyawarah Desa. Kedua, musyawarah ditingkat desa dalam musyawarah ini aspirasi pembangunan dari masing-masing dusun dibahas dalam musyawarah ini, didalam musyawah desa (I Made Adi, Tedi Putu Eka ,2015)

Menurut Mathis dan Jackson dalam Landa (2015:5) menyatakan bahwa pengawasan adalah cara mengamati kinerja dari pegawai yang didasarkan dengan adanya standar untuk ukuran kinerja, adanya informasi yang menjadi sasaran dalam mencapai hasil yang disampaikan kepada pegawai dan memastikan bahwa kualitas dalam menilai suatu pekerjaan 
dapat tercapai. Sedangkan menurut ( Ni Putu, Tedi Ni Wayan 2016 ) pengawasan adalah proses pemantauan yang dilakukan untuk mengetahui sejauh mana kinerja yang dilakukan pegawai apakah sudah sesuai dengan aturan yang ditetapkan dan segala proses yang dilaksanakan sudah sesuai dengan yang disepakati sehingga dapat diketahui perencanaan yang sudah dibuat tersebut telah sesuai atau menyimpang dari tujuan yang telah ditentukan. Dari penelitian diatas dapat disimpulkan bahwa Pengawasan diperlukan untuk mengetahui apakah perencanaan yang telah disusun dapat berjalan secara efisien, efektif, dan ekonomis.

Transparansi menjadi sangat penting bagi pelaksanaan fungsi-fungsi pemerintah dalam menjalankan mandat dari rakyat. Mengingat pemerintah saat memiliki kewenangan mengambil berbagai keputusan penting yang berdampak bagi orang banyak, pemerintah harus menyediakan informasi yang lengkap mengenai apa yang dikerjakannya (Faridah.2015) sementara menurut (Suci Indah, 2015) Transparansi artinya dalam menjalankan pemerintahan, pemerintah mengungapkan hal-hal yang sifatnya material secara berkala kepada pihak-pihak yang memiliki kepentingan, dalam hal ini yaitu masyarakat luas sehingga prinsip keterbukaan yang memungkinkan masyarakat untuk mengetahui dan mendapatkan akses informasi seluas- luasnya tentang keuangan daerah. Beda halnya dengan (Iqsan, 2015) transparansi merupakan keterbukaan informasi yang mudah dipahami oleh masyarakat, adanya publikasi mengenai detail anggaran desa, adanya laporan berkala mengenai pengelolaan anggaran kepada masyarakat dengan kata lain suatu alat yang sangat penting untuk menjembatani kebutuhan masyarakat tentang keingintahuan masyarakat terhadap jalannya pemerintahan didaerah mereka sendiri dan merupakan tanggung jawab pemerintah itu sendiri untuk memberikan informasi yang dibutuhkan oleh masyarakat. (Farida, 2015) Transparansi menjadi sangat penting bagi pelaksanaan fungsi -fungsi pemerintah dalam menjalankan mandat dari rakyat. Mengingat pemerintah saat memiliki kewenangan mengambil berbagai keputusan penting yang berdampak bagi orang banyak, pemerintah harus menyediakan informasi yang lengkap mengenai apa yang dikerjakannya. Dengan transparansi, kebohongan sulit untuk disembunyikan.Dengan demikian transparansi menjadi instrumen penting yang dapat menyelamatkan uang rakyat dari perbuatan korupsi.

Pertanggungjawaban menurut Anthony merupakan organisasi yang dipimpin oleh seorang manajer yang bertanggungjawab terhadap aktivitas yang dilakukan. (Anthony, 2002:111). Sedangkan menurut (Kadek Sutrawati, , 2016.) Akuntabilitas pengelolaan dana desa dimulai dari tahap perencanaan, perangkat desa melakukan musyawara untuk membahas Rencana Pembangunan Jangka Menengah Desa.Dalam pelaksanaandana desa pengajuan pendanaan dana desa disertai dengan RAB dan bendahara desa melakukan pembayaran sesuai dengan RAB yang telah disetujui oleh sekretaris desa. Dalam penatausahaan penerimaan dan pengeluaran kas yang dilakukan oleh bendahara desa dilakukan menggunakan pembukuan yang dimasukan kedalam buku kas umum, buku pembantu pajak dan buku bank.Pelaporandana desa mengenai dana yang digunakan dari tahap I, II, dan III. Dalam pertanggungjawaban perangkat desa mempertanggungjawabkan Laporan Realisasi Pelaksanaan Anggaran Pendapatan dan Belanja Desa.

\section{Metodologi Penelitian}

\section{Populasi dan Sampel Penelitian}

Populasi dalam penelitian ini adalah seluruh perangkat desa pada Kabupaten Karawang. Jumlah ideal perangkat desa setiap kelurahan adalah 17 orang dan kecamatan 30 orang. Ukuran dan Teknik Pengambilan Sampel Pendapat Gay dan Diehl (1992) ini mengasumsikan bahwa semakin banyak sampel yang diambil maka akan semakin 
representative dan hasilnya dapat di genelisir. Namun ukuran sampel yang diterima akan sangat bergantung pada jenis penelitiannya. Untuk analisis regresi, disarankan adalah $15-20$ observasi per independen variabel (Hair, dkk, 2006:166). Dengan demikian, dalam penelitian ini kami memutuskan menggunakan 100 responden untuk mendapatkan data penelitian.

\section{Variabel dan Pengukuran Variabel}

Dalam penelitian ini menggunakan tiga jenis variable yaitu variable bebas (independent) dan variable antara (interviening) serta variable terikat (dependent).

Definisi Operasional Variabel dalam penelitian ini mengacu dari Modul APBDes Partisipatif (2003), yang dijabarkan sebagai berikut:

1) Variabel Perencanaan APBDes

Sebelum APBDes dibahas makah harus didahului dengan tahapa nmusyawarah yaitu tahap pertama ,musyawarah pembangunan di tingkat dusun untuk menyerap aspirasi dari masing-masing $\mathrm{RT} / \mathrm{RW}$, musyawarah ini dipimpin oleh masing-masing kepaladusun. Hasil-hasil dari penyerapan aspirasi ditingkat dusun dituangkan dalam bentuk usulan yang akan dibawa tingkat musyawarah desa. Kedua, musyawarah ditingkat desa dalam musyawarah ini aspiras pembangunan dari masing-masing dusun dibahas dalam musyawarah ini.

2) Variabel Pelaksanaan APBDes

Bahwa Variabel Pelaksanaan APBDes (X2) adalah: pelaksanaan APBDes Adalah menjabarkan rencana pembangunan yang tercantum dalam APBDes untuk dilaksanakan dengan sebaik-baiknya. Dalam pelaksanaan pembangunan desa ini harus melalui tahapan sosialisasi kepada masyarakat, agar mengetahui bahwa akan diadakan pembangunan desa dan berpartisipasi aktif dalam pembangunan.

3) Variabel Pengawasan APBDes

Bahwa Variabel X2 adalah: Pengawasan adalah proses mengarahkan dan menilai suatu pelaksanaan kegiatan. Pengawasan APBDes sangat diperlukan guna menjamin agar proses pelaksanaan APBDes berjalan sesuai dengan rencana dan ketentua peraturan perundang-undangan yang berlaku. Sehingga dengan adanya pengawasan yang efektif dan berkala, maka penyimpangan dalam pelaksanaan APBDes dapat diminimalisir.

4) Variabel Transparansi APBDes

Kriteria transparansi anggaran yang dapat digunakan untuk menguku transparansi dalam perencanaan dan penganggaran seperti yang dikemukakan Transparansi merupakan organisasi secara terbuka menyediakanin formasi yang material dan relevan sertamudah diakses dan dipahami oleh pemakaian kepentingan (Atmadja, 2013: 19)

\section{Metode dan Analisis Data}

Penelitian ini mengguanakan teknik kuesioner dalam mengumpulkan data.. Sebelum kuesioner disebar maka perlu dilakukan uji Validitas dan reliabilitas. Kuesioner yang disebar, menggunakan skala Likert, dan hasil yang di dapat kemudian dilakukan skoring.

\section{Uji Validitas}

Uji validitas yang digunakan dalam penelitian ini adalah Validitas Konstruk, yaitu uji validitas untuk melihat konsistensi antara komponen konstruk yang satu dengan yang lainnya, jika semua komponen tersebut konsisten antara yang satu dengan yang lainnya maka komponen tersebut valid. 


\section{UjiReliabilitas}

Uji Reliabilitas menunjukkan ketepatan, kemantapan, dan homogen itasalatukur yang dipakai. Pada penelitian ini Uji Reliabilitas menggunakan Alpha Cronbach, dimana batasnya tidak lebih kecil dari 0,7.

\section{Uji Asumsi Klasik}

Dalam penelitian ini, beberapa uji asumsi klasik yang harus dilakukan sebelum analisis regresi dilakukan.

\section{Rancangan Analisis dan Uji Hipotesis}

Analisis yang digunakan dalam penelitian ini, verifikatif. Uji Verikatif, digunakan dalam Uji T dan Uji F. Uji T (Uji Parsial), digunakan untuk menguji berarti atau tidaknya hubungan variabel- variabel Independen secara parsial dengan variable intervening dan variable dependen. Uji F (Uji Simultan), digunakan untuk mengetahui hubungan antara variable independen dan variable dependen, apakah dependen benar benar berpengaruh secara simultan (bersama-sama) terhadapvariabel intervening maupun terhadap variable dependen.

Disamping kedua uji di atas, dalam uji ini dapat dilihat seberapa besar Koefisien Determinannya. Koefisien determinasi $\left(\mathrm{R}^{2}\right)$ dilakukan untuk melihat adanya hubungan yang sempurna atau tidak, yang ditunjukkan pada apakah perubahan variable akan diikuti oleh variable terikat. Pengujian ini dengan melihat nilai R Square $\left(\mathrm{R}^{2}\right)$. Nilai koefisien determinasi adalah antara 0 sampai dengan 1 .Selanjutnya nilai $\mathrm{R}^{2}$ yang kecil berarti kemampuan variabel-variabelin dependen dalam menjelaskan variasi variabel dependent sangat terbatas. Nilai yang mendekati 1 berarti variable variabel independent memberikan hamper semuain formasi yang dibutuhka nuntuk memprediksi variasi dependent (Ghozali, 2005).

\section{Hasil Penelitian dan Pembahasan \\ Analisis Deskriptif Sampel}

Populasi dalam penelitian ini adalah seluruh perangkat desa pada Kabupaten Karawang. Jumlah pasti berapa banyak perangkat desa, Jumlah ideal pegawai setiap kelurahan adalah 17 orang dan kecamatan 30 orang, 100 responden untuk mendapatkan data penelitian.

\section{Uji Validitas dan Reliabilitas}

Pengujian validitas variabel: Dengan bantuan program Microsoft Excel, hasil ujicoba validitas instrumen kuesioner menggunakan Korelasi Product Moment, dengan jumlah responden 100 hasil yang diperoleh adalah sebagai berikut:

1. Variabel Perencanaan APBDes (X1): Jumlah kuesioner Valid, yang memiliki $r$ hitung di atas $\mathrm{r}$ tabel $(0,444)$, berjumlah 10 pertanyaan, dan 2 kuesioner dinyatakan tidak valid, yakni dengan $r$ hitung di bawah 0,4444 .

2. Variabel Pelaksanaan APBDes (X2): Jumlah kuesioner Valid, yang memiliki $r$ hitung di atas $r$ tabel $(0,444)$, berjumlah 9 pertanyaan, dan 1 kuesioner dinyatakan tidak valid, yakni dengan $r$ hitung di bawah 0,4444 .

3. Variabel Pengawasan APBDesX3: Jumlah kuesioner Valid, yang memiliki $r$ hitung di atas $r$ tabel $(0,444)$, berjumlah 10 pertanyaan, dan 2 kuesioner dinyatakan tidak valid, yakni dengan $r$ hitung di bawah 0,4444 .

4. Variabel Transparansi APBDes (Y): Jumlah kuesioner Valid, yang memiliki $r$ hitung di atas $r$ tabel $(0,444)$, berjumlah 11 pertanyaan, dan 1 kuesioner dinyatakan tidak valid, yakni dengan $r$ hitung di bawah 0,4444 . 
Sedangkan hasil ujicoba reliabilitas kuesioner, dapat dilihat pada tabel dibawah ini:

\section{Tabel 2}

\section{Hasil Reliabilitas}

\begin{tabular}{cccc}
\hline Variabel & Alpha Cronbach & Batasan & Reliabilitas \\
\hline X1 & 0.913 & 0.7 & Reliabel \\
X2 & 0.943 & 0.7 & Reliabel \\
X3 & 0.926 & 0.7 & Reliabel \\
Y & 0.952 & 0.7 & Reliabel \\
\hline
\end{tabular}

Sumber :Diolah 2017

Suatu instrument penelitian mengindikasikan memilik ireliabilitas yang memadai jika koefisien alpha Cronbach lebih besar atau sama dengan 0,70. Dengan demikian dapat disimpulkan bahwa variabel-variabel yang diteliti adalah reliabel.

Tabel 3

Uji Normalitas

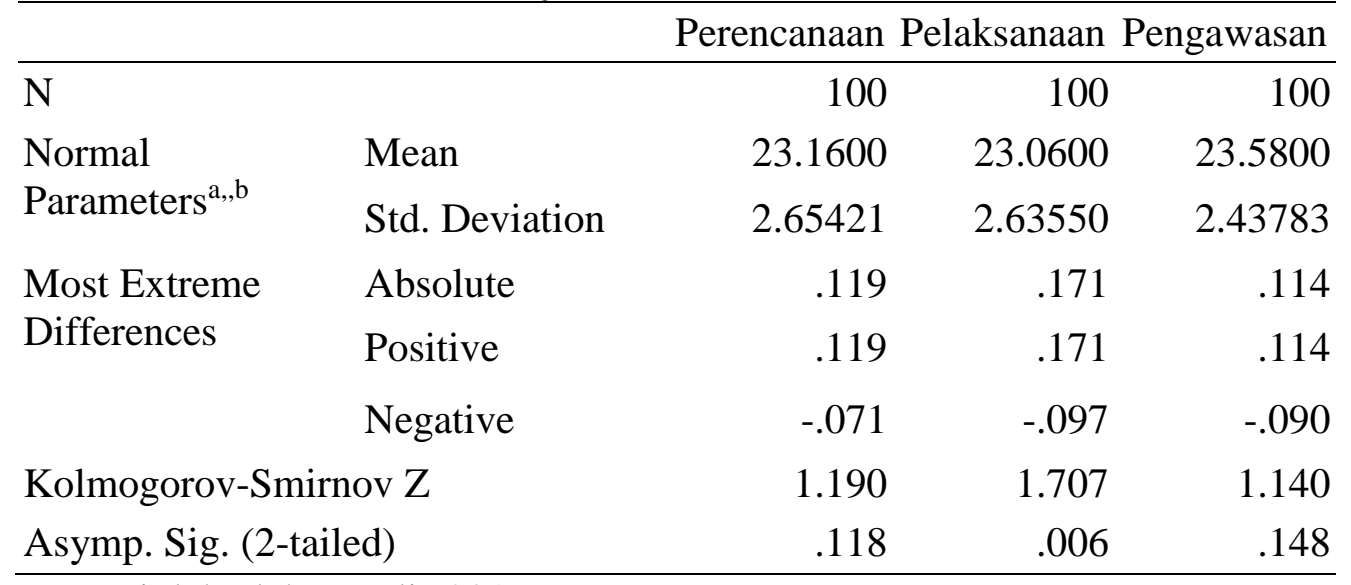

Diolah oleh penulis 2017

Dari hasil uji normalitas diatas terlihat bahwa semua skor variabel $\rho$-value lebih besardari $\alpha=0.05$, sehingga: data dari populasi diatas berdistribusi normal

\section{Tabel 4}

\section{Uji Multikolinieritas}

\begin{tabular}{|c|c|c|}
\hline VariabelDependen & VariabelIndependen & Nilai $r$ square $\left(r^{2}\right)$ \\
\hline Pelaksanaan & Perencanaan & 0,613 \\
\hline Pengawasan & Pelaksanaan & 0,448 \\
\hline Pengawasan & Perencanaan & 0,419 \\
\hline Nilai $\mathrm{R}^{2}$ & 0,714 & \\
\hline
\end{tabular}

Diolah oleh penulis 2017

Dari tabel di atas dapat diketahui bahwa nilai koefisien $\mathrm{r}^{2}$ yang diperoleh seluruhnya bernilai lebih kecil dari pada nilai koefisien determinasi $\left(\mathrm{R}^{2}\right)$. Dengan demikian dapat disimpulkan bahwa tidak terjadi masalah multikolinearitas pada model regresi.

Pengujian Hipotesis.

Pengujian Hipotesis 1: Pengaruh Perencanaan APBDes $\left(\mathrm{X}_{1}\right)$ terhadap Transparansi APBDes (Y) 
Tabel 5

Coefficients

\begin{tabular}{|c|c|c|c|c|c|c|}
\hline \multirow{2}{*}{\multicolumn{2}{|c|}{ Model }} & \multicolumn{2}{|c|}{$\begin{array}{l}\text { Unstandardized } \\
\text { Coefficients }\end{array}$} & \multirow{2}{*}{$\begin{array}{c}\begin{array}{c}\text { Standardize } \\
\mathrm{d} \\
\text { Coefficients }\end{array} \\
\text { Beta }\end{array}$} & \multirow[b]{2}{*}{$\mathrm{t}$} & \multirow[b]{2}{*}{ Sig. } \\
\hline & & $\mathrm{B}$ & Std. Error & & & \\
\hline \multirow[t]{2}{*}{1} & (Constant) & 13.303 & 2.539 & & 5.240 & .000 \\
\hline & $\begin{array}{l}\text { Perencanaa } \\
\mathrm{n}\end{array}$ & 1.102 & .109 & .715 & 10.120 & .000 \\
\hline
\end{tabular}

Sumber : Hasil penglahan data, 2017

Untuk pengaruh Perencanaan APBDes $\left(\mathrm{X}_{1}\right)$ secara parsial terhadap Transparansi APBDes $(Y)$, dengan tingkat signifikansi $(\alpha)=5 \%$ dan degree of freedom $(\mathrm{df})=(\mathrm{n}-2)=100$ $-2=98$ sehingga diperoleh $\mathrm{t}$ tabel $=0,6770$. Berdasarkan tabel di atas, dapat dilihat bahwa nilai Sig. $(0,00<\alpha(0,05)$ dan $t$ hitung $(10.120)>t$ tabel $(0,6770)$ sehingga Ho ditolak. Dengan demikian dapat disimpulkan bahwa terdapat pengaruh secara parsial Perencanaan APBDes terhadap Transparansi APBDes.

Pengujian Hipotesis 2: Pengaruh Pelaksanaan APBDes $\left(\mathrm{X}_{1}\right)$ terhadap Transparansi APBDes (Y)

Tabel 6

Coefficients

\begin{tabular}{llrrrrr}
\hline & \multicolumn{5}{c}{$\begin{array}{l}\text { Unstandardized } \\
\text { Coefficients }\end{array}$} & \multicolumn{2}{c}{$\begin{array}{c}\text { Standardized } \\
\text { Coefficients }\end{array}$} & \\
\multicolumn{1}{l}{ Model } & \multicolumn{1}{c}{ B } & Std. Error & Beta & \multicolumn{1}{c}{ t } & \multicolumn{1}{c}{ Sig. } \\
\hline 1 & (Constant) & 10.861 & 2.273 & & 4.778 & .000 \\
& X2 & 1.213 & .098 & .781 & 12.382 & .000 \\
\hline
\end{tabular}

Sumber : Hasil penglahan data, 2017

Untuk pengaruh Pelaksanaan APBDes $\left(\mathrm{X}_{1}\right)$ secara parsial terhadap Transparansi APBDes $(Y)$, dengan tingkat signifikansi $(\alpha)=5 \%$ dan degree of freedom $(\mathrm{df})=(\mathrm{n}-2)=100$ $-2=98$ sehingga diperoleh $\mathrm{t}$ tabel $=0,6770$. Berdasarkan tabel di atas, dapat dilihat bahwa nilai Sig. $(0,00<\alpha(0,05)$ dan $t$ hitung $(12.328)>t$ tabel $(0,6770)$ sehingga Ho ditolak. Dengan demikian dapat disimpulkan bahwa terdapat pengaruh secara parsial Pelaksanaan APBDes terhadap Transparansi APBDes.

Pengujian Hipotesis 3: Pengaruh Pengawasan APBDes $\left(\mathrm{X}_{1}\right)$ terhadap Transparansi APBDes (Y)

\section{Tabel 7}

Coeffisien

\begin{tabular}{|c|c|c|c|c|c|c|}
\hline \multirow{2}{*}{\multicolumn{2}{|c|}{ Model }} & \multicolumn{2}{|c|}{$\begin{array}{l}\text { Unstandardized } \\
\text { Coefficients }\end{array}$} & \multirow{2}{*}{$\begin{array}{c}\text { Standardized } \\
\text { Coefficients } \\
\text { Beta }\end{array}$} & \multirow[b]{2}{*}{$\mathrm{t}$} & \multirow[b]{2}{*}{ Sig. } \\
\hline & & $\mathrm{B}$ & Std. Error & & & \\
\hline \multirow[t]{2}{*}{1} & (Constant) & 9.258 & 2.672 & & 3.465 & .001 \\
\hline & X3 & 1.254 & .113 & .747 & 11.125 & .000 \\
\hline
\end{tabular}


Untuk pengaruh Pengawasan APBDes(X3) terhadap TransparansiAPBDes (Y), dengan tingkat signifikansi $(\alpha)=5 \%$ dan degree of freedom $(\mathrm{df})=(\mathrm{n}-2)=100-2=98$ sehingga diperoleh $\mathrm{t}$ tabel $=0,6770$. Berdasarkan tabel di atas,dapat dilihat bahwa nilai Sig. $(0,00<\alpha(0,05)$ dan $t$ hitung $(11.125)>t$ tabel $(1,675)$ sehingga Ho ditolak. Dengan demikian dapat disimpulkan bahwa terdapat pengaruh secara signifikan Pengawasan APBDes terhadap Transparansi APBDes

Pengujian Hipotesis 4: Pengaruh Secara Simultan Perencanaan APBDes(X), Pelaksanaan APBDes $\left(\mathbf{X}_{2}\right)$ dan Pengawasan APBDes $\left(\mathbf{X}_{3}\right)$ terhadap Transparansi APBDes (Y)

Pengaruh Perencanaan APBDes $\left(\mathrm{X}_{1}\right)$, Pelaksanaan APBDes $\left(\mathrm{X}_{2}\right)$ dan Pengawasan APBDes (X3) secara simultan (keseluruhan) terhadap Transparansi APBDes(Y) diperoleh hasil sebagai berikut :

Tabel 8

Model Summary

\begin{tabular}{llrrr}
\hline $\begin{array}{l}\text { Mod } \\
\text { el }\end{array}$ & R & $\begin{array}{c}\text { R } \\
\text { Square }\end{array}$ & $\begin{array}{c}\text { Adjusted R } \\
\text { Square }\end{array}$ & $\begin{array}{c}\text { Std. Error } \\
\text { of the } \\
\text { Estimate }\end{array}$ \\
\hline 1 & $.845^{\mathrm{a}}$ & .714 & .705 & 2.23288 \\
\hline
\end{tabular}

Sumber : Hasil pengolahan data, 2017

Nilai $\mathrm{R}^{2}$ dari tabel Model Summary menunjukkan bahwa $71.4 \%$ dari variance Transparansi APBDes, dapat dijelaskan variabel Perencanaan APBDes, Pelaksanaan APBDes dan Pengawasan APBDes.

Tabel 9

ANOVA $^{\mathrm{b}}$

\begin{tabular}{|c|c|c|c|c|c|c|}
\hline Model & & $\begin{array}{l}\text { Sum of } \\
\text { Squares }\end{array}$ & Df & Mean Square & $\mathrm{F}$ & Sig. \\
\hline & Regression & 1183.768 & 3 & 394.589 & 79.143 & $.000^{\mathrm{a}}$ \\
\hline & Residual & 473.646 & 95 & 4.986 & & \\
\hline & Total & 1657.414 & 98 & & & \\
\hline
\end{tabular}

Sumber : Hasil pengolahan data, 2017

a.Predictors: (Constant), X3, X2, X1

b. Dependent Variable: Y

Pengaruh Perencanaan APBDes $\left(\mathrm{X}_{1}\right)$, Pelaksanaan APBDes $\left(\mathrm{X}_{2}\right)$, Pengawasan APBDes $\left(\mathrm{X}_{3}\right)$ secara simultan (keseluruhan) terhadap Transparansi APBDes (Y) dapat dilihat pada tabel di atas, dengan tingkat signifikansi $(\alpha)=5 \%$ dan degree of freedom $(\mathrm{df})=(\mathrm{n}-2)=100-2=98$ sehingga diperoleh $\mathrm{f}$ tabel $=$ 3,09. Berdasarkan tabel di atas, dapat dilihat bahwa nilai Sig. $(0,000)<\alpha(0,05)$ dan $F_{\text {hitung }}(79,143)>F_{\text {tabel }}(3,09)$ sehingga Ho ditolak. Dengan demikian dapat disimpulkan bahwa terdapat pengaruh simultan dari Perencanaan APBDes, Pelaksanaan APBDes, Pengawasan APBDes terhadap Transparansi APBDes.

\section{Pembahasan}

Pengujian Hipotesis 1: Pengaruh Perencanaan APBDes $\left(\mathrm{X}_{1}\right)$ terhadap Transparansi APBDes (Y). 
Dilihat dari hasil pengujian hipotesis maka dapat disimpulkan bahwa terdapat pengaruh secara parsial Perencanaan APBDes terhadap Transparansi APBDes. Adanya perencanaan APBDes yang sesuai dengan anggaran yang telah disetujui maka akan membuat transparansi APBDes kepada masayarakat, dan dana yang didapatkan dapat dipertanggungjawabkan kepada masayarakat desa. Melakukan perencanaan dengan melibatkan aparatur desa, mulai dari RT sampai dengan kepala desa akan membuat transparansi APBDes dengan baik. Sehingga Perencanaan APBDes yang baik akan mempengaruhi Transparansi APBDes yang baik dan dapat dipertanggungjawabkan.

Pengujian Hipotesis 2: Pengaruh Pelaksanaan APBDes $\left(\mathrm{X}_{1}\right)$ terhadap Transparansi APBDes (Y)

Dilihat dari hasil olah data dalam pengujian hipotesis yang menghasilkan bahwa terdapat pengaruh secara parsial Pelaksanaan APBDes terhadap Transparansi APBDes. Pelaksanaan pembangunan desa sudah dilakukan dengan baik, dengan cara memberi sosialisasi terlebih dahulu sebelum melakukan pembangunan desa. Dengan melihat pelaksanaan pembangunan desa dengan melihat transparansi APBDes. Pelaksanaan APBDes yang baik akan membantu pembangunan desa, dengan menunjukkan Transperansi APBdes yang baik pula dengan melibatkan masyarakat.

Pengujian Hipotesis 3: Pengaruh Pengawasan APBDes $\left(X_{1}\right)$ terhadap Transparansi APBDes (Y)

Hasil olah data dan pengujian hipotesis menunjukkan bahwa terdapat pengaruh secara signifikan Pengawasan APBDes terhadap Transparansi APBDes. Melakukan pengawasan yang baik akan memberi dampak juga terhadap transparansi. Bentuk Pengawasan APBDes dengan cara pelaksanaan APBdes sesuai dengan rencana dan ketentuan peraturan perundangundangan yang berlaku, dengan adanya pengawasan yang efektif dan berkala akan meminimalisir penyimpangan dalam pelaksanaan APBDes. Pengawasan APBDes yang baik, akan membuat Transparansi APBDes berjalan dengan baik.

Pengujian Hipotesis 4: Pengaruh Secara Simultan Perencanaan APBDes( $\left.X_{1}\right)$, Pelaksanaan APBDes $\left(\mathbf{X}_{2}\right)$ dan Pengawasan APBDes $\left(\mathbf{X}_{3}\right)$ terhadap Transparansi APBDes (Y)

Secara simultan hasil dari olah data dan pengujian hipotesis adalah bahwa terdapat pengaruh simultan dari Perencanaan APBDes, Pelaksanaan APBDes, Pengawasan APBDes terhadap Transparansi APBDes. Data yang diperoleh menunjukkan bahwa $71.4 \%$ dari variance Transparansi APBDes, dapat dijelaskan variabel Perencanaan APBDes, Pelaksanaan APBDes dan Pengawasan APBDes. Dan 28,6\% dipengaruhi olrh variabel lain, yang tidak diteliti dalam penelitian ini. Secara simultan berarti semua variabel independen (X) secara bersama-sama mempengaruhi variabel dependen (Y), hal ini menunjukkan bahwa adanya penecanaan yang baik, sehinga dapat dilaksanakan dengan baik dan pengawasan yang berkala akan membuat Transparansi APBDes yang baik. Transparansi APBDes yang baik, akan dapat dipertanggungjawabkan kepada masyarakat.

\section{Kesimpulan ,Implikasi Keterbatasan Penelitian Dan Saran Kesimpulan}

Penelitian ini memberikan bukti empiris bahwa terdapat pengaruh Perencanaan APBDes, Pelaksanaan APBDes, Pengawasan APBDes secara parsial terhadap Transparansi APBDes. Disamping itu, penelitian ini juga membuktikan terdapat pengaruh simultan dari Perencanaan APBDes, Pelaksanaan APBDes, Pengawasan APBDes terhadap Transparansi APBDes.. Hasil perhitungan didapat nilai Sig. $(0,000)<\alpha(0,05)$ dan $\mathrm{F}$ hitung $(79,143)>\mathrm{F}$ tabel $(3,09)$ sehingga Ho ditolak. Nilai $\mathrm{R}^{2}$ dari tabel Model 
Summary menunjukkan bahwa $71.4 \%$ dari variance Transparansi APBDes, dapat dijelaskan variabel Perencanaan APBDes, Pelaksanaan APBDes dan Pengawasan APBDes.

\section{Implikasi}

Pembuktian adanya pengaruh variabel independen terhadap variabel dependen pada penelitian ini, berimplikasi terhadap keharusan peningkatan kualitas pengelolaan APBDes. Dengan demikian, beberapa saran yang dapat diberikan antara lain: (1) Pemerintah sebaiknya dapat memberikan pendampingan yang intens dan berkesinambungan dalam pengelolaan APBDes, yang dimulai sejak perencanaan, pelaksanaan dan adanya pengawasan.(2) penentuan sarana Informasi, yang tepat dan cepat demi tercapainya Transparansi, berdasarkan kondisi yang sesuai pada desa setempat.

\section{Saran Untuk penelitian selanjutnya}

Penelitian selanjutnya sebaiknya juga memperhatikan akuntabilitas dari Laporan Pertanggungjawaban dari APBDes, sehingga bentuk pertanggungjawaban laporan ini akan sesuai dengan prinsip-prinsip keuangan yang berlaku.

\section{DAFTAR PUSTAKA}

Amirruddin, Muhammadiah, Ruskin 2012 Transparansi Pengelolaan Anggaran Pendapatan Dan Belanja Desa Di Desa Pertasi Kencana Kecamatan Kalaena Kabupaten Luwu Timur, Vol. II No. 1 Jurnal Otoritas

Adisasmito, Rahardjo. 2011. Manajemen Pemerintah Daerah. Yogyakarta: Graha Ilmu

Atmadja, Anantawikrama tunggu. 2013. Akuntansi manajemen sektor publik. Singaraja: Universitas Brajijaya.

Eka Herdi Nugraha 2016 Pengelolaan Dana Desa Dalam Pembangunan Desa Dan Pemberdayaan Masyarakat Desa Di Desa Hargotirto Kecamatan Kokap Kabupaten Kulon Progo Jurusan Pendidikan Kewarganegaraan Dan Hukum, Fakultas Ilmu Sosial, Universitas Negeri Yogyakarta

Faridah ,Bambang Suryono , 2015Transparansi Dan Akuntabilitas Pemerintah Desa Dalam Pengelolaan Anggaran Pendapatan Dan Belanja Desa (Apbdes) Jurnal Ilmu \& Riset Akuntansi Vol. 4 No. 5 Sekolah Tinggi Ilmu Ekonomi Indonesia (Stiesia) Surabaya

Gozali, Imam. 2005. Aplikasi Analisis Multivariate dengan Program SPSS Edisi 3.Semarang: Badan Penerbit Universitas Diponegoro

Gay, L.R. dan Diehl, P.L. (1992), Research Methods for Business and. Management, MacMillan Publishing Company, New York

Hair, J.F., W.C. Black, B.J. Babin, R.E. anderson, R.L.Tatham, (2006). Multivariate Data Analysis, 6 Ed., New Jersey : Prentice Hall 
Iqsan 2016 Transparansi Pemerintah Desa Dalam Penyusunan Anggaran Pendapatan Dan Belanja Desa (Apbdes) Di Desa Long Nah Kecamatan Muara Ancalong Kabupaten Kutai Timur eJournal Ilmu Pemerintahan, 2016, 4(1): 230-240 ISSN 2477-2631,

Kadek Sutrawati, , 2016. Peran Perangkat Desa Dalam Akuntabilitas Pengelolaan Dana Desa (Studi Pada Desa Pudaria Jaya Kecamatan Moramo) . Skripsi. Jurusan Akuntansi. Fakultas Ekonomi Dan Bisnis. UniversItas Halu Oleo.

Mardiasmo. 2009. Akuntansi Sektor Publik. Andi.Yogyakarta

Ni Putu ,Tedi Ni Wayan 2014.Fungsi Pengawasan Badan Permusyawaratan Desa Dalam Penyerapan Anggaran Pendapatan Dan Belanja Desa Menurut Uu No. 6 Tahun 2014(Studi Kasus Di Desa Riang Gede Kecamatan Penebel Kabupaten Tabanan)

Peraturan Pemerintah Republik Indonesia Nomor 72 Tahun 2005 Desa. . Lembaran Negara Republik Indonesia Tahun 2005 Nomor 158. Jakarta

Suryo Pratolo, Winarso, 2013 Artikel Jurnal Model Implementasi Sistem Pengelolaan Keuangan Desa (Pp No.32 Tahun 2004) Untuk Mendukung Terwujudnya Kinerja Pemerintahan Desa Dan Pelayanan Publik- Kabupaten Indragiri Hilir Riau. Universitas Muhamadiyah Yogyakarta

Suci Indah ,Sugeng Praptoyo 2015 Jurnal Akuntabilitas Dan Transparansi Pertanggungjawaban Anggaran Pendapatan Belanja Desa (Apbdes) Jurnal Ilmu \& Riset Akuntansi Vol. 4 No. 8

Undang -Undang No 6 Tahun 2014 tentang Desa Peraturan Pemerintah Nomor 43 Tahun 2014 tentang Peraturan Pelaksanaan

Peraturan Menteri Dalam Negeri no 37 tahun 2007 tentang Pedoman Pengelolaan Keuangan Desa

Copyright (c) 2020 Sri Suartini, Hari Sulistiyo, Syamsul Huda 